Western University Scholarship@Western

Aboriginal Policy Research Consortium International (APRCi)

2007

\title{
Aboriginal Rights Deliberated
}

Fred Bennett

Follow this and additional works at: https://ir.lib.uwo.ca/aprci

Part of the Other Sociology Commons

Citation of this paper:

Bennett, Fred, "Aboriginal Rights Deliberated" (2007). Aboriginal Policy Research Consortium International (APRCi). 303.

https://ir.lib.uwo.ca/aprci/303 
This article was downloaded by: [University of Western Ontario]

On: 07 December 2012, At: 07:16

Publisher: Routledge

Informa Ltd Registered in England and Wales Registered Number: 1072954

Registered office: Mortimer House, 37-41 Mortimer Street, London W1T 3J H, UK

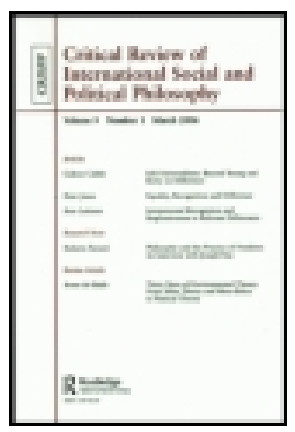

\title{
Critical Review of International Social and Political Philosophy
}

Publication details, including instructions for authors and subscription information:

http:// www. tandfonline.com/loi/fcri20

\section{Aboriginal Rights Deliberated}

\author{
Fred Bennett ${ }^{a}$ \\ ${ }^{a}$ Ottawa, Canada \\ Version of record first published: 20 Sep 2007.
}

To cite this article: Fred Bennett (2007): Aboriginal Rights Deliberated, Critical Review of International Social and Political Philosophy, 10:3, 339-358

To link to this article: http:// dx. doi.org/ 10.1080/ 13698230701400320

\section{PLEASE SCROLL DOWN FOR ARTICLE}

Full terms and conditions of use: http://www.tandfonline.com/page/termsand-conditions

This article may be used for research, teaching, and private study purposes. Any substantial or systematic reproduction, redistribution, reselling, loan, sublicensing, systematic supply, or distribution in any form to anyone is expressly forbidden.

The publisher does not give any warranty express or implied or make any representation that the contents will be complete or accurate or up to date. The accuracy of any instructions, formulae, and drug doses should be independently verified with primary sources. The publisher shall not be liable for any loss, actions, claims, proceedings, demand, or costs or damages whatsoever or howsoever caused arising directly or indirectly in connection with or arising out of the use of this material. 


\title{
Aboriginal Rights Deliberated
}

\author{
FRED BENNETT
}

Ottawa, Canada

\begin{abstract}
Democratic deliberation is credited with a variety of virtues, including its possible usefulness in resolving, or at least ameliorating, inter-cultural conflicts. This paper questions this claim. First, it overlooks that the facts and principles involved in these conflicts generally prove contestable and that such contestation is likely to be greater the less homogenous societies are. Second, it neglects that many, if not most, citizens have neither the time nor the inclination to acquire the conceptual and factual knowledge needed to try and overcome these differences. As a result, the more inclusive and popular deliberation becomes, the less suitable it may be for overcoming cross cultural disagreements. Indeed, it has the potential to exacerbate rather than narrow the differences between majorities and minorities. These conclusions are drawn from an empirical review of a Canadian debate about aboriginal rights that followed a controversial Supreme Court of Canada decision and comparing the character of deliberation in three contexts: the legal community, the print media and legislative bodies.
\end{abstract}

KEY WORDS: Democratic deliberation, aboriginal rights, cultural disagreement

Since at least 1990 democratic theory has taken 'a strong deliberative turn' (Dryzek 2001: 1). Proponents credit deliberation with many moral and epistemological virtues: legitimization of the ultimate choice; promoting consensus; improving participants' intellectual and moral qualities; 'superior' (however defined) decisions, innate desirability; and so on. Central to arguments supporting deliberation is the claim of 'cognitive virtue;' it facilitates good decisions by increasing public knowledge (Pellizzoni 2001: 67). To obtain this cognitive benefit, and to ensure that any decision is perceived as legitimate, debate must be inclusive, open to all and all points of view. This position is often identified with Jurgen Habermas, who argues for the benefits of debate at all levels of society but stresses the importance of civil society debate (Habermas 1996). Others, skeptical of the benefits of such wideranging debates, argue that more limited debates amongst those knowledgeable about the issues and vested with political or legal responsibility may be more useful. John Rawls is the most prominent theorist who stresses the view that deliberation

Correspondence Address: 160 George St., Apt. 1406, Ottawa, Canada, K1N 9M2. Email: Bennett.fred@ sympatico.ca 
constrained by norms of public reason is normatively necessary only in strictly political institutions, such as the courts and legislatures (Rawls 1993; 1999).

Deliberation is often said to be particularly useful for addressing the claims of cultural minorities because it emphasizes reasons rather than numbers and is less culturally biased than other decision tools, stressing procedural norms of dialogue rather than culturally specific norms of justice (Bohman 1996; Young 2000; Valadez 2001; Benhabib 2002). Cillion McBride also argues that deliberation 'is sensitive to [minorities'] claims of justice' because it emphasizes 'a conception of impartial public reason to distinguish between legitimate and illegitimate interests' (McBride 2003: 114). Other theorists, however, argue that deliberation, particularly intercultural deliberation, leads to polarization rather than consensus (Shapiro 1999; Sunstein 2002).

In this paper, I focus on a particular case arising in the context of the debate in Canada about the rights and status of Canada's indigenous peoples (or 'First Nations'). I hope to accomplish two things: first I want to determine if deliberation did or did not contribute to overcoming intercultural tensions; and second I try to shed light on the relevance of the debate's forum in determining whether it does or not. I begin by briefly explaining the broad context of Canadian-indigenous relations, focusing on the different types of disagreement at play. Subsequently, I discuss the issue of debate forums. This is followed by an examination of the public debate sparked by a Canadian legal case - Delgamunkw v. British Columbia - with the aim of elucidating public deliberation's usefulness in resolving intercultural differences. I conclude with a discussion of the implications for my findings for inter-cultural democratic deliberation.

\section{First Nations, the Canadian State and the Tasks of Deliberation}

According to Alan Cairns, 'the central question in aboriginal/non-aboriginal relations in Canada ... has always been, is the goal a single society with one basic model of belonging, or is the goal a kind of parallelism-a side by side coexistence or some intermediate position' (Cairns 2000: 47). The first view - the goal is a single form of citizenship - no longer has much academic support but resonates with the public. Two general arguments underpin this position: empirically, special status results in social isolation and relative economic deprivation for aboriginals compared to other Canadians; normatively, it conflicts with the liberal ideal of equal citizenship. The second view - parallel development through aboriginal self-government, the recognition and enforcement of treaties, and so on, within the structure of the Canadian state - argues that the relationship of individual aboriginals with the Canadian state is inherently different to that of other Canadian citizens. Various normative arguments support this view. Patrick Macklem categorizes these as follows: prior occupancy, prior sovereignty, treaties, self-determination and preservation of minority culture (Macklem 1995). He concludes that a right to self-government - special status in my terminology - is best supported by all five justifications taken together (Macklem 1995: 219). Prior occupancy, prior sovereignty and treaties are arguments 
based on historical events. Most contemporary liberal theorists argue from within a present-oriented justice paradigm, such as that of John Rawls or Jurgen Habermas. Historical justifications fit more readily into Robert Nozick's framework of natural rights, whereby 'the holdings of a person are just if he is entitled to them by the principles of justice in acquisition and transfer, or by the principle of rectification of injustice' (Nozick 1974: 153). Macklem, for his part, argues that the two perspectives can be reconciled by converting both the prior occupancy and the original sovereignty arguments into contemporary equality claims (Macklem 2001: 78-85). In a mirror image of the economic argument used by the opposing view, it is also often argued that restoration of a land base to First Nations will rectify the poverty faced by many aboriginals.

Thus, the two positions are both supported by a mixture of normative principle and factual assertion. For example, prior occupancy, which as we shall see the Supreme Court stresses, depends, first, on the moral claim that it gives rise to a claim to land, self-government and so on, which trumps (some) other considerations, and, second, on a factual claim that a specific group did in fact possess a particular piece of land. In order to debate intelligently the application of the normative principle of prior occupancy to a given situation, factual claims must be adjudicated and normative arguments evaluated. These issues are not beyond the comprehension of the average citizen, if he or she has the time and inclination to study them, but they may create difficulties for any attempt to resolve differences by debate.

Luigi Pellizzoni argues that, when there are differences of opinion as to both fact and value, three types of controversy can be distinguished. First, there may be conflicting descriptions of the facts but shared principles; second, the description of the facts may be similar but based on different principles; and finally, there may be different principles and different descriptions of the facts (Pellizzoni 2001: 70). The first two possibilities - contested facts with shared principles or shared facts but contested principles - admit at least the possibility of an agreement. However, when both facts and principles are contested agreement will be hard to find:

If there is agreement on the facts, a shared solution may be found even if any underlying conflict on principles remains unresolved; but conflict over the facts creates far greater obstacles against finding a solution viewed by everyone as fair. The parties insist on the relevance of different conceptual frames. They may be using the same terms but they speak different languages. (Pellizzoni 2001: 70).

There is empirical evidence that prospects for agreement are even worse than Pellizzoni postulates; differences on values alone (principles) may also be intractable. Citing 'persuasive argument theory', Tali Mendelberg writes:

On matters of value, opportunities for deliberation are likely to turn antideliberative. And even if they manage to turn argument-centered, they are unlikely to change minds. (Mendelberg 2002: 160-161) ${ }^{1}$ 
The issue of special status for aboriginals is one in which both facts and principles are disputed. In these circumstances, does public deliberation help or hinder the search for intercultural accord? Does it matter if the debate is inclusive and unconstrained, as advocated by Habermas, or restricted to certain public settings, as Rawls argues? The following section discusses the arguments around this latter question.

\section{Deliberate Where?}

For the majority of Canadians, aboriginal issues are of marginal interest most of the time. Before they can be debated they have to come to the attention of political institutions and the general public. Habermas holds that deliberation draws much of its moral and epistemological force from citizen debate outside the political and judicial structures of the state. He does not denigrate the value of deliberation within state structures, but adopts a 'two track' view of democratic legitimacy. One track focuses on formal political and legal institutions; the second track stresses the informal public sphere (Habermas 1996: 486-487). It is Habermas's view that many of the major issues of recent political debate - the environment, genetic engineering, feminism, immigration, etc. - have come to the public agenda through an energized civil society. Indeed, he argues that it is often the confrontational tactics of civil society actors that brings such issues to wide public attention, thus forcing political and institutional actors to take note (Habermas 1996: 374). Ultimately however, decisions are taken by legislative bodies, which are, or should be, themselves deliberative bodies. Courts, and particularly constitutional courts, while not necessarily deliberative bodies in Habermas's sense, play the essential role of ensuring 'that the process of lawmaking takes place under the legitimating conditions of deliberative politics' (Habermas 1996: 274). Habermas, however, is discussing debate in what is, implicitly at least, a culturally homogeneous civil society.

Rawls's model of deliberation differs somewhat from that of Habermas. Rawls focuses much of his discussion of the requirements of public reason on what he calls 'the public political form' which is, in essence, judges, chief executives and legislators and candidates for public office (Rawls 1999: 575). The Supreme Court (of the United States) is seen as the 'exemplar of public reason' (Rawls 1993: 231). Debate in these institutions is not, of course, inclusive in the sense of including all citizens. It is rather amongst and between professionals (politicians, judges, lawyers, etc.) who, in theory at least, are knowledgeable about the issue at hand. However, in other institutions of society, Rawls, like Habermas, upholds the idea of unrestricted debate, writing that 'the idea of public reason does not apply to the background culture with its many forms of public reason nor to media of any kind' (Rawls 1999: 576).

Canada's First Nations, however, are not actors in Habermas's culturally homogeneous society but distinct political and cultural societies. They are organized as separate legal entities, with a variety of constitutional provisions, laws and judicial decisions defining their evolving relationship with the Canadian state. It is possible to argue that the existence of separate legally recognized publics is not a barrier to, 
but necessary for, inter-cultural dialogue. Separate publics permit 'a fairer, more equal, and more reciprocal debate' (James 1999: 81-82). However, their existence raises the question of how dialogue between the separate and culturally different public spheres can, in the absence of a mutually shared 'lifeworld' or sense of the common good, take the form of deliberation as envisaged by deliberative theorists and not degenerate into simple strategic bargaining (James 2003: 164).

Nancy Fraser addresses this point, arguing that Habermas's early account of the public sphere stressed its singularity, 'its claim to be the public arena', and that this 'confinement of public life to a single overarching public sphere' was, for Habermas, 'a positive and desirable state of affairs' (Fraser 1992: 122). She goes on to argue, correctly in my view, that separate 'subaltern counter publics' are necessary to compensate for societal inequalities. Without separate public spheres, disadvantaged minorities 'would have no arenas among themselves for deliberation about their needs, objectives, and strategies' (Fraser 1992: 123). But multiple publics must have a shared forum in which to debate. Geoff Ely suggests that we theorize this necessary forum of interaction 'as the structured setting where cultural and ideological contest or negotiation among a variety of publics takes place', and not, as in Habermas's original formulation, 'as the spontaneous and class-specific achievement of the bourgeoisie in some sufficient sense' (Ely 1992: 306). A comparison of Rawls's model with that of Habermas, as modified by Fraser and Ely, of how public deliberation should work is the focus of my investigation. The following section describes the origins of the case, the courts' decisions and the debate that followed. In different ways, both models prove more problematic than their proponents had imagined.

\section{Delgamuukw v. British Columbia}

Delgaтииkw involves the claim of an aboriginal group in the province of British Columbia to ownership and governance over its traditional territory. In most of Canada, the government signed treaties with the aboriginal inhabitants, by which aboriginals sold much of their original territory while reserving certain specified lands for their exclusive use. In British Columbia, however, such treaties were never signed; the provincial government simply started expropriating aboriginal lands without consent. Therefore, there is no legal document by which aboriginal peoples relinquished title over their traditional territories. This circumstance has created a situation where there are vastly different perceptions about legal title to the land. The provincial government has historically assumed that its title is valid while aboriginal communities have tried for decades to assert their title to the land. One of the most active communities is the 'Gitksan' Indian people, and it is their claim that was the subject of the important case decided in 1997 by the Canadian Supreme Court. I will first describe the basic details of the legal case, and then examine the civil society debate it generated.

The 1997 decision of the Supreme Court of Canada in Delgamuиkw v. British Columbia ended a legal process begun in 1984. The appellants, Gitksan and Wet'suwet'en hereditary chiefs, had filed suit in the British Columbia Supreme Court 
seeking recognition of title to their traditional territories: 'full ownership, selfgovernment, and other aboriginal rights, over 22,000 square miles of west central British Columbia' (Elliot 1998: 98). Their claim was largely rejected at trial and in the British Columbia Court of Appeal. They appealed to the Supreme Court of Canada, which overturned the original decision and ordered a new trial. The court did not recognize any new title to the land, or create any new institutions of selfgovernment; but it did insist that the lower courts had not properly interpreted the facts and the law. In particular, it argued that the trial judge had erred in largely ignoring oral histories and other oral evidence given at trial (Delgamuukw (S.C.): 1067).

The court also emphasized that aboriginal title has a special status, deserving of distinctive protection. Aboriginal title to land is not, the court wrote, identical to normal legal title to land; it is sui generis and 'arises from the prior occupation of Canada by aboriginal peoples' (Delgamuukw (S.C.): 1082). It is 'a collective right to land held by all members of an aboriginal nation' which 'cannot be transferred, sold or surrendered to anyone other than the Crown' (Delgamuukw (S.C.): 1083, 1081). If a claim to aboriginal title were successfully made for a given tract of land, it would provide substantial control over it (Delgamuukw (S.C.): 1087). A First Nation claiming aboriginal title must meet the following criteria:

(i) the land must have been occupied prior to [British] sovereignty. (ii) if present occupation is relied on as proof of occupation presovereignty, there must be a continuity between present and presovereignty occupation, and (iii) at sovereignty, that occupation must have been exclusive. (Delgamuukw (S.C.): 1097).

While aboriginal title has a special status and importance, it is not absolute. In the event a claim to aboriginal title were proved, it would still be subject to infringement by both provincial and federal governments in pursuit of a 'compelling and substantial' legislative objective, which may include such things as conservation, economic development and the settlement of foreign populations (Delgamuukw (S.C.): 1107-1111). Such infringement would be subject to various judicial tests: the scope of the infringement; consultation with the aboriginals holding the title; and the payment of compensation (Delgamuukw (S.C.):1109). The court also deferred resolving the claim to self-government because "errors of fact made by the trial judge' made it impossible 'to determine whether the claim to self-government has been made out' (Delgamuukw (S.C.): 1114).

Delgamuukw v. British Columbia attracted some public commentary as it worked its way through the courts; the Supreme Court decision moved it to the center of national debate. On the one hand, one might think that the decision was ideally suited for a respectful debate. First, the court's commentary on aboriginal title relied for its justification on 'prior occupancy'. While this is by no means uncontroversial in academic circles - it conflicts with present-oriented conceptions of justice - it does enjoy wide support. It is a well-developed theoretical perspective that lends itself to moral and political debate. Second, the court's decision had no immediate 
practical impact; the underlying substantive issue, whether or not the appellants actually had aboriginal title, was referred back to the lower courts for retrial (or for negotiation between the parties). To the best of my knowledge, the issue is still outstanding today. Consequently, nobody's property rights or other economic interests were immediately at risk. If public deliberation is a useful way of promoting intercultural understanding and resolving conflicts, as its proponents argue, this case should have been an ideal exemplar.

On the other hand, the Delgamuukw decision and its history contained precisely that mixture of disputed facts and principles which deliberation's critics argue can lead to increased conflict: Should prior occupancy convey special status? Are there meaningful ways of comparing the degree of 'civilization' of different societies? Would it matter, morally, if there were? Was aboriginal title ever extinguished? Had the aboriginals actually occupied the land continuously and exclusively? Is oral history reliable? It is this mixture of fact and value that, in my view, makes an investigation of the debate relevant for assessing the claims of deliberation theorists. Furthermore the discussion took place in the different forums of society - the courts (more generally, the legal community), the media and the legislatures, making it possible to evaluate the differences.

\section{The Legal Debate}

From the start of the litigation process, the parties differed over matters of both fact and value. The original trial highlighted two opposing views of the First Nations, their history and culture, their rights, and their place in contemporary Canada. The aboriginals viewed themselves as the current representatives of an organized historical culture with its own laws and customs, equal in value to any other (Gitksan and Wet'suwet'en Hereditary Chiefs 1989: 21). The opposing view - aboriginal societies occupied a low level on the ladder of human development - has been described as the 'traditional white view' in British Columbia (Tennant 1992: 77). This was certainly the position the British Columbia Crown took at trial. The trial judge summarized its position as follows:

The defendants [the British Columbia Crown] ... point to the absence of any written history, wheeled vehicles, or beasts of burden, and suggest the Gitksan and Wet'suwet'en civilizations, if they qualify for that description, fall within a much lower, even primitive order. (Delgamuukw (trial): 31)

The trial judge himself, while he acknowledged the aboriginals' view of themselves, took the traditional white view put forward by the British Columbia Crown:

The plaintiffs' ancestors had no written language, no horses or wheeled vehicles, slavery and starvation was common, and there is no doubt, to quote Hobbes, that aboriginal life in the territory was, at best 'nasty, brutish and short'. (Delgamuиkw (trial):13) 
Implicit in these putatively factual statements are views about the normative importance of different past levels of technical and social development for the rightness of claims made today. Needless to say, the plaintiffs took a different view. They claimed to have had and still to have their own system of law that 'shares common features with the legal systems of all civilized societies' (Gitksan and Wet-suwet'en Hereditary Chiefs 1989: 35). The trial judge concluded that he was 'not persuaded' as a matter of historical fact that 'their [the plaintiffs'] ancestors practiced universal or even uniform customs', let alone laws (Delgamuukw (trial): 213). The judge was equally dismissive of much of the evidence presented by the plaintiffs, especially the oral evidence. The plaintiffs argued that, if the court denied the validity of oral evidence not confirmed by other scientific means, this would be 'to disregard the distinctive Gitksan and Wet'suwet'en system of validating historical facts' and that this, in turn, would undermine 'the very possibility of dialogue' (Gitksan and Wet'suwet'en Hereditary Chiefs 1989: 39-40). The oral evidence was admitted at trial, but the judge concluded 'that much of the plaintiffs' historical evidence is not literally true' (Delgamuukw (trial): 49). As to the substantive claims to ownership and self-government rights, the trial court's decision was almost a total defeat for the plaintiffs (Elliot 1998: 98).

The plaintiffs fared little better as appellants in the British Columbia Court of Appeal. The majority accepted, with certain minor differences, the trial court's reasoning, which was largely the view of the British Columbia Crown. The appellants were held to "have no property rights to the lands in question and no jurisdiction to enact laws that would conflict with provincial laws that apply in and to the areas claimed' (Delgamuukw (appeal): 3). There was, however, a dissenting opinion:

The appeal should be allowed and a declaration made that the Gitksan and Wet'suwet'en peoples have ... as common law rights an aboriginal title to occupy, possess, use and enjoy all or some of the land within the claimed territory. (Delgamuukw (appeal): 6, 7)

Thus, with the exception of the Appeal Court dissent, the case arrived at the Supreme Court as a victory for the Crown and the traditional view of aboriginals and their place in Canadian society. As I discussed above, however, the Supreme Court majority view presented a very different view of the relevant issues. The appellants -i.e. the original aboriginal plaintiffs - restated the views they had put forward at trial. They used the dissenting Appeal Court opinion to support their position (Wet'suwet'en Hereditary Chiefs 1997; Gitksan Hereditary Chiefs 1997) The respondents - the Attorney General of Canada and Her Majesty the Queen in Right of the Province of British Columbia - did the same (Province of British Columbia 1997; Canada, the Attorney General of 1997). The majority decision of the Supreme Court summarizes, fairly in my view, the positions of the parties to the case as well as the decisions of the two lower courts (including the dissenting opinion in the British Columbia Court of Appeal). The court does, on occasion, directly address the trial judge's reasoning, particularly that dealing with the appropriate weight to give 
to oral history (Delgamuukw (S.C.): 1071-1080). It also directly addressed the positions of the parties on the content of aboriginal title, arguing that the correct position 'in fact, lies somewhere in between these positions' (Delgamuukw (S.C.): 1080). Nevertheless, the bulk of the court's reasoning relies more on the court's own previous decisions and academic legal articles than on the arguments of the lower courts, the parties or the interveners. The result is more of a debate within a particular segment of the legal community than an engagement with the arguments of the parties or the lower courts. It should be noted that the courts' discussions, while intelligent and knowledgeable about the issues, did not arrive at or even approach a consensus. The Supreme Court disagreed with the trial judge and two of the three Appellate Court judges; its own decision was not unanimous. The ultimate decision was, however, more favorable to the First Nations' positions (although exactly how favorable is open to discussion) than either of the two lower court decisions.

After the court's decision, the debate in the (academic) legal community was wide-ranging and vigorous. Some thought that the decision, while not perfect, represented a substantial advance for aboriginal rights. Kent McNeil, for example, argued that the decision provided 'more scope for the use of oral histories'; it also 'defined Aboriginal title, explained what is necessary to prove it, clarified the extent of federal authority over it, and addressed the issues of constitutional protection and infringement' (McNeil 2001: 323). ${ }^{2}$ While the court's view of aboriginal title was subject to certain strictures, the decision 'nonetheless came down on the side of the Gitksan and Wet'suwet'en on the vital issue of natural resources' (McNeil 2001: 327). However, McNeil does ask 'why the onus is on aboriginal peoples to prove their title' and not on the Crown 'when we all know that they were here occupying lands when the newcomers arrived' (McNeil 2001: 328). He also questions the scope the decision leaves for governments to infringe aboriginal title for a variety of purposes (McNeil 2001: 329). Several other commentators also wrote articles that, while different in detail, generally felt the decision was an advance for aboriginal rights (Wilkins 2000; Joffee 2000).

A significant number of legal academics expressed negative views, almost uniformly on the grounds that it did not go far enough. For example, Gordon Christie writes:

the complete picture of aboriginal title offered in Delgamuukw ... rests on underpinnings which make the entire picture conceptually unstable and generally unacceptable ... (both on moral and doctrinal grounds). (Christie 20002001: 115)

William F. Flanagan argues that 'contrary to some media reports', the decision 'may not be an unqualified success for aboriginal claimants' in that it seems especially tailored to avoid the full legal consequences of normal property law (Flanagan 1998: 285). ${ }^{3}$ And John Borrows argues that 'the Court's decision in Delgamuukw is infused with the Court's acceptance of a subsequent claimant's nonconsensual assertion of rights over a prior owner's land' and that the court's ultimate support 
of the colonization, subjection, and domination of aboriginal peoples in British Columbia, despite its attempt to provide protections for aboriginal peoples in this process, is not a 'morally and politically defensible conception of aboriginal rights' (Borrows 2001: 594, 615-661). ${ }^{4}$

What conclusions can we draw from this debate about the theory and practice of democratic deliberation? First, the articles cited (and others not cited) attempt to engage the decision's reasoning. The decision was long and complex, it drew on a previous court decisions, and it made, as I noted above, extensive reference to the legal literature. Therefore, to address the court's rationale required a degree of legal sophistication. There was no agreement, even amongst experts, as to the legal wisdom, moral rectitude or implications for aboriginal rights of the decision. Second, no article that I encountered in the legal literature expressed opposition to the decision as too favorable to the aboriginal point of view. ${ }^{5}$ It seems reasonable to conclude that the academic legal community was already, before this particular issue arose, largely of one mind about both the normative weight of prior occupancy (and the other principles supporting special status) and the facts as presented by the original plaintiffs. In other words, the legal debate did not lead to a greater degree of agreement; the agreement as to the general rightness of the aboriginals' claims preexisted the debate. As we shall see, this outlook is sharply at odds with the general public's reaction to the decision and many of the reactions expressed in the legislative branches of the federal and provincial governments. Given that the Supreme Court itself places a great deal of importance on debate within the academic community in reaching its decision, one can only conclude that the court is, to some extent at least, debating with a very narrow public.

\section{The Media Debate}

I reviewed the coverage given the decision by all major Canadian daily newspapers. I reviewed all articles containing the word 'Delgamuukw' and read all except those which were only factual recaps of the decision and in which the reference to Delgaтииkw was clearly tangential to their subject. Those cited are, I hope, representative of the ideas presented that have relevance for deliberative democracy.

The Supreme Court's decision was handed down on Thursday, 11 December 1997. Early coverage recognized the decision's importance and tentatively raised some of the issues which would come to dominate the public discussion: economic uncertainty, the court's views on oral history, the power of the Supreme Court, and so on. For example, in a reasonably neutral editorial on 13 December 1997, the major national English language daily newspaper, the Globe and Mail, saw the decision as a step forward in resolving the open issues between First Nations and the Canadian state (Globe and Mail 1997: D6). The Financial Post, a business-oriented newspaper, again in a reasonably neutral way, also stressed the need for future negotiations, in order to avoid economic uncertainty (Financial Post 1997: 26).

Negative reaction appeared quickly. Gordon Gibson, a Vancouver-based columnist writing in the Globe and Mail, declared the decision 'the most important political 
event in the second half of this century', claiming that it undermined 'all Crown title in the province, thereby threatening natural resource revenues and freezing investment' (Gibson 1997: A21). A letter to the editor from Martyn Brown, identified as the executive director, The Citizens' Voice on Native Claims, Vancouver, supported Gibson's position claiming that 'the province's unfettered title to virtually all Crown land is now in question', and 'even private property may be subject to claims for compensation of infringements against aboriginal title'. The decision was also characterized as anti-egalitarian because 'instead of leading to greater equality of all Canadians, it will reinforce special status for aboriginal Canadians forever' which, according to the writer, is 'exactly the opposite of what most Canadians hope to achieve through treaty negotiations' (Brown 1997: D7). ${ }^{6}$

Other commentators raised the role of the judiciary. Jeffery Simpson, for example, wrote that the decision 'represents judicial activism on a massive scale' (Simpson. 1998: A18). A letter to the Globe and Mail stated: 'We must not permit the Supreme Court to put back the clock without so much as a glance at the Canadian population' (Joslin 1998: A-18). Preston Manning, then leader of the Reform Party, the Official Opposition in Parliament, advocated the creation of a parliamentary 'judicial reform committee' to 'review decisions of the Supreme Court' and advise Parliament of possible remedial measures, such as the use of the notwithstanding clause of the Constitution (Manning 1998: A21).

The issue of the weight and value of oral history attracted considerable negative commentary. In the New Brunswick Telegraph Journal, David Cunningham wrote that 'according to some legal experts, the ruling's most radical component is its requirement that the courts give equal consideration to aboriginal oral evidence' (Cunningham 1998). A subsequent article in the same paper, written by John Robson, identified as the deputy editorial pages editor of the Ottawa Citizen, went even further. The Supreme Court, said the writer, 'ruled that aboriginal traditional oral knowledge had the same standing as European legal prejudices in favor of actual evidence'. He compared this to the type of evidence produced against the defendants at the notorious Stalinist purge trials, writing:

So more Indians can claim land if they produce some snaggle-toothed old hag to sing an off-key song asserting that their people used to live there. And if someone says she just made that song up that morning she'll sing another one saying that it comes from the ancestors. (Robson 1998)

A more general issue raised by Delgamuиkw was equality - the claim that special treatment of aboriginals violates the basic equality of all citizens. An editorial in the Ottawa Citizen argued that 'the most troubling aspect, not only of self-government, but of aboriginal policy generally' is the creation of different and inherently unequal categories of citizens: 'Most Canadians believe - deeply - that race should have no bearing at law, that we are all equal before the law regardless of our skin color or ancestry'. While aboriginals are, like all Canadians, protected by antidiscrimination laws, we are 'left with a strange form of equality' in that 'laws that discriminate 
against aboriginals are offensive to equality and therefore unsustainable' while laws discriminating 'in favor of aboriginals ... are warmly approved and have proliferated' (Ottawa Citizen 1998: B5).

The greatest concern of the decision's opponents was, however, its potential economic consequences. A Globe and Mail front-page article by John Gray entitled 'Who Owns This Land? Aboriginal Rights Cast Pall over B.C. Economy' stated that immediately after the court's view of aboriginal title was published 'native people claimed their title'. He quoted Jerry Lambert, head of the BC Business Council, as saying 'that for the first time, the question of land claims has surfaced as a concern of the Canadian investment community'. The 'uncertainty around land claims' was having 'a deterrent effect on potential investors' (Gray 1998:A1, A10). A writer in The Province made a similar point, arguing that the decision 'is raising uncertainty and fears that are costing B.C. big money' (Fournier 1998: A44).

There were fewer arguments supporting the decision. Occasional articles responded to specific criticisms of the decision. For example, Stan Persky defended the acceptance by the court of oral history, writing that 'oral history is very much at the heart of native culture' (Persky 1998: A19). Other articles defended the Supreme Court from the charge that it is out of touch with the people. Terry Glavin cited polling data indicating that a majority of the citizens of British Columbia support the involvement of the courts in the resolution of aboriginal issues (Glavin 1998: A19). Several articles, which I will not cite, provided reasonably sophisticated explanations of the role of the courts in liberal constitutional democracies as the protectors of rights and liberties. And Stephen Hume mounted a detailed defense of Delgamuиkw against those 'who don't know their own history and don't much care to learn it' and who view the Court's decision as 'a frivolous bit of mischief conjured out of thin air'(Hume 1998a: G4).

Persky and Hume (and the fact that I cite them again indicates the relative scarcity of favorable views) each presented moral arguments supporting the decision. Persky addressed the view that holds that current Canadians, especially recent immigrants, need not take responsibility for past injustices, arguing that 'moral responsibility isn't a matter of individual guilt and/or denial' (Persky 1998a: A19). He went on to denounce those who use the idea of equality to attack land claims as hypocritical, arguing that it is perverse to claim that the rectification of centuries of injustice can constitute a violation of equality. Hume, for his part, wrote that the decision, far from being 'a bizarre invention by mischievous radicals', is rather 'the logical culmination of 200 years of careful and conservative jurisprudence' and is 'evidence of the integrity of our democracy, proof that justice will eventually be done, however slowly' (Hume 1998b: G5).

\section{The Legislative Debate}

The decision was discussed in the House of Commons and its various committees. As a general observation, it is fair to say that the issues raised in Parliament reflected those in the print media. It is also the case that positions put forward 
reflected party divisions, with members of the (left-leaning) New Democratic Party generally in favor of the decision, (right-leaning) Reform Party members opposed, and government members belonging to the (centrist) Liberal Party taking a cautious middle ground. In an 11 March 1998 exchange, for example, Gordon Earle of the New Democratic Party called upon the government to respond to the decision by negotiating 'in good faith with aboriginal peoples to resolve issues around land claims, the sharing of natural resources and self-government'. Stan Keys, the Liberal parliamentary secretary to the minister of transport, responded that the government 'is acting on the principle that the inherent right of selfgovernment is an existing aboriginal legal right within our constitution' and that the government's approach was to set 'aside the legal and constitutional debates that have stymied the process' (Canada 1998a: 4741). However, much of the parliamentary debate was driven by the Reform Party's opposition to the decision, and by their dislike of the role played by the Supreme Court. Reform Party member Philip Mayford, for example, noted the court's reliance on academic literature: 'the justices referred not to legal precedents but to the literature from law schools on which at least their judgment was based in part'(Canada 1998a: 5536). One member also criticized the court's position on oral history, saying it will 'supplement common law with a new system of law in which equal credence is to be given in aboriginal cases, to the aboriginal perspective'(Canada 1998a: 74967497). Economic uncertainty and the potential cost of the decision were also much discussed. One member argued that 'ownership of every square inch of British Columbia is in doubt', with the result that 'industry is saying not one more nickel of investment until this is settled' (Canada 1998a: 7411). And the leader of the Reform Party argued that:

[the] decision has created economic uncertainty in every sector of the British Columbia economy that requires land or resources ... The decision has created a potential taxpayer liability of literally tens of billions of dollars. These impacts are big enough to cripple the British Columbia economy. (Canada 1998a: 7698)

The equality argument against special status for aboriginal people was also raised, with one member asking: 'Does the federal government not understand that the pursuit of separate development is apartheid in Canada?' (Canada 1998a: 7497). Equality, on this view, requires identical treatment of all:

We simply have to treat people on the basis of equality in the country: equal opportunity for everyone involved ... We want aboriginal people to have the same rights and protections that every Canadian enjoys. (Canada 1999: 905-906)

The argument that special rights arise from the aboriginals' prior occupancy of the land was explicitly addressed and rejected: 
We cannot go back in history 110 or 120 years and try to use that to justify what is happening today. We have to move forward in a constructive united front for all Canadians. If we do not, the blood will be on our hands. (Canada 1998a: 7498)

The debate in the Legislative Assembly of British Columbia was greatly influenced by the discussion of the proposed Nisga'a treaty which was happening at the same time. Much comment, which I will not cite, deals with the possible influence of the decision on this and other treaty negotiations. There was more discussion about the potential impacts of the decision and the need to come to terms with British Columbia's history of interactions with its First Nations than there was of the underlying moral rationales for the decision. Gordon Wilson, for example, said the decision:

indicates clearly that aboriginal people have rights. These rights run with the land, and they have rights to their land...it is essential for us to recognize that there is a legacy of interaction between first nations and non-first nations people in British Columbia that has left a long and very hurtful past that needs to be dealt with. (British Columbia 1998/99: 6825)

And B. Goodacre lauded the decision for having clarified government's responsibilities: 'We [now] have the basis ... to seriously consider what it is that we as a government are responsible for doing, in terms of negotiations with first nations (British Columbia 1998/99: 6730-6731). Nevertheless, some thought the decision lacked clarity. One member stated:

The problem with Delgamuukw is that you have two different readings ... Many first nations see Delgamuukw as effectively saying 'We have ownership of all the land'. And we are saying: 'No, rather there is a test that you need to go through'. (British Columbia 1998/99: 15207).

There was, of course, some opposition to the role played by the court, with one member saying: 'The fact that the court decision confirmed ... the existence of aboriginal title does not necessarily make it so' (British Columbia 1998/99: 6844). The major concern was the potential impact on the economy. Wilson, speaking of Northern British Columbia, stated:

I think it's important for us to hear and understand the concerns now expressed by people who live in the north, especially in light of the Supreme Court ruling in Delgamuukw ... No northern jobs commissioner is going to solve the economic uncertainty until we recognize what that ruling has done. (British Columbia 1998/99: 8308)

There was, however, very little discussion of the justifications, or lack thereof, for the decision. 


\section{Implications}

What lessons for deliberative theory and its possible role in advancing intercultural understanding can one draw from the debate that followed the court's decision? As I outlined above, there are five general lines of argument in favor of special status for aboriginal people. They are a mixture of factual and normative claims and all are contestable and contested. The Supreme Court's rationale, at least as it related to aboriginal title, was squarely based on one of those arguments, prior occupancy: 'it is now clear that although aboriginal title was recognized by the proclamation, it arises from prior occupation of Canada by aboriginal peoples' (Delgamuukw (S.C.): 1082).

Prior occupancy as a normative principle (or more precisely the view that the time of arrival of one's ancestors conveys different rights and privileges) can certainly be criticized. For example, it conflicts with the principle that all current citizens should enjoy equal rights. Of course, the conflict of basic normative principles is not unusual. However, any resolution, in theory or practice, requires that the conflict be addressed and resolved. Both principles in their pure forms cannot be instantiated at the same time. That the court did not address this difficulty suggests it fell short of Rawls's view of such bodies as 'exemplars of public reason'. Yet, Habermas's faith in wider public debate fared no better. Though the moral merit of prior occupancy of a territory by one's ancestors was raised, outside the academic literature I did not come across any reasoned attempt to reconcile it with the idea that citizens should enjoy equal rights. In fact, the broader media and legislative debate tended to add to and amplify the deficiencies of the legal debate.

Proponents of deliberation, such as Habermas, who stress the importance of generalized public debate want to expand the scope and nature of democracy in liberal democratic societies. They want citizens, not just legislators and courts, to take an active role in debating major issues. In furtherance of this goal, they stress the desirability of an inclusive debate, one in which all can potentially participate, contribute and have their contributions taken seriously. As I noted at the beginning, a central benefit claimed for deliberation is that it "permits the dissection of a problem and the devising of better solutions than those reached by negotiation or the aggregation of preferences, or through a discussion confined to a handful of initiates' (Pellizzoni 2001: 60). Because it is impossible to know in advance which are the better arguments, all arguments should be considered. Unfortunately, most citizens have neither the time nor the inclination to acquire the requisite knowledge. Consequently, what one often gets are pure statements of opinion. Even if participants are disposed to display an openness to the perspectives of cultural minorities, which is a questionable assumption in itself, this is not sufficient in the absence of the requisite factual and conceptual base. In the broad public debate sparked by the Supreme Court's decision we see little or no indication of any such willingness by participants to obtain the required knowledge of the facts or of the ways in which the conflict between different normative principles might be resolved. What, then, is the basis for the optimistic expectations for democratic deliberation? If the debate were 
about a simple issue and among people sharing a common conceptual base, agreement, or at least reduced disagreement, might be attainable. In circumstances where the issues are complex and the participants differ as to both facts and values, discussion may simply serve to confirm the participants pre-existing positions.

My description of the Delgamuukw debate seems to support the skeptics who think that in many circumstances discussion exacerbates disagreement rather than the reverse. It raises questions about whether or not it is realistic to think that deliberation can move many members of groups with different interests and cultural backgrounds toward a common view of the issues. There was no indication that debate in the media or the legislatures did anything to change peoples' positions. Even the reduced level of disagreement in the legal academic community appeared to arise from a pre-existing shared view rather than the 'force of the better argument'. Delgaтииkw raised issues of both fact and principle. The 'traditional white' view of aboriginal societies, their history and their present circumstances simply does not address the aboriginals' view of the past and the present. The two views differ both on the facts, on how the facts should be interpreted, and even on what constitutes a fact. At the level of principle, the two sides are often, as Pellizzoni says, 'using the same terms' - both speak of the importance of equality - but they are speaking, metaphorically at least, different languages. Participants, in practice, speak only to, or perhaps more accurately, are only heard by, those who already think like them. This lack of dialogue is not the result of opposition between aboriginal and non-aboriginal. While it should be noted that the public debate was overwhelmingly dominated by the perspectives of non-aboriginals, there were arguments sympathetic to the aboriginal position put forward by non-aboriginals. Therefore, the paucity of deliberation is not an issue of cultural incommensurability: both sides are capable of understanding each other. From the evidence, the large majority of non-aboriginals simply do not try to understand the aboriginal perspective.

Inclusiveness is a major consideration for most proponents of deliberation. It is felt to be important, both to add legitimacy to any eventual decision and, from the cognitive perspective, to ensure that relevant perspectives and information are taken into account. Unfortunately, this case suggests that the wider the debate - i.e., the more it approaches Habermas's ideal - the less substantive and issue oriented it is. Within the courts and related legal and academic circles, the debate wrestled with the issues and put forward reasoned arguments. By contrast, the media and legislative debates were both largely superficial, with positions put forward as final and not subject to revision, although the legislative debates did, to some extent at least, surpass the public in terms of knowledge and openness.

Though deliberation in the courts may have been superior to that of the public at large, it too had limitations. As I noted, the issues highlighted by the court fell short of the full range of available public reasons, arguably casting doubt on Rawls's identification of public and constitutional reasoning, at least as carried out by the judiciary. He also seems to have been mistaken in his expectation that a Supreme Court will act as a role model, setting the terms of the broader public debate in beneficial ways by focusing attention on the principles at stake. 
In the event, the fact that the issue entered the broad public agenda by way of a court decision had practically the opposite effect. Court cases focus on issues of law and standing to produce winners and losers. This process tends to discourage reasoned deliberation of basic principles, in this case of whether or not prior occupancy should give First Nations special status. There was little if any debate in the public sphere of this issue, even though it was at the heart of the court's decision. Rather than discuss the moral merits of the decision, much debate focused on the role of courts, and whether or not the Supreme Court should 'impose' a judicial solution on what many viewed as a political problem. The court's position on oral histories also loomed large in the public debate and served to highlight the polemical issue of the relative worth of different cultures' ways of doing things. And, as I noted above, the fact that the Supreme Court had spoken served as a way for some to avoid taking potentially unpopular positions in favor of the aboriginal perspective. The pursuit of a constitutional, legal claim brought the issue to the public agenda, but that confrontation, so necessary to get on the agenda of the overarching public sphere, ultimately subverted debate by allowing some to hide behind the authority of the Supreme Court, and distorted it by focusing attention on issues such as the admissibility of evidence and the role of the courts which were not central to the moral and political matter at hand.

The obvious response to the above conclusions is that 'deliberative democratic theory is not a predictive social perspective', but rather 'a critical yardstick'. ${ }^{7}$ On this view, current institutional structures must - to a greater or lesser degree undergo structural change if deliberation is to fulfill its potential for more legitimate and cognitively better outcomes. ${ }^{8} \mathrm{I}$ am unable to address any of the various proposals which have been put forward to achieve this improvement. The question which can be asked by skeptics about the value of public deliberation, and which must be answered by proponents of the inclusive democratic deliberation advocated Habermas, is whether it is at all likely, ever, that significant numbers of ordinary citizens will display the willingness to devote the time and effort informed debate about complex public matters requires. And is it likely that they will ever do so when it concerns the demands of cultural minorities, people with different worldviews to their own and interests that conflict with theirs. At present, encouraging public deliberation of minority demands that potentially impose a cost on the dominant majority does not appear to be a promising tool, either from the minority's perspective or that of promoting inter-cultural understanding. Worse, though elite forums, such as legislatures and especially courts, may perform better, they too fall short of being exemplary sources of public reasoning idealized by Rawls and can serve to further weaken, rather than improve, that of the public themselves.

\section{Acknowledgements}

Will Kymlicka read and commented on an earlier version of this paper. As always, his advice was wise, incisive and, not least, prompt in coming. While the views expressed are my own, they are, hopefully, all the better for Will's help. Comments 
and suggestions by the editor of this journal were invaluable to achieving whatever coherence and consistency the paper has. Jay Drydyk also made valuable suggestions on the paper's content. The Social Sciences and Humanities Research Council of Canada provided the funding for a post-doctoral fellowship which allowed me to research and write this paper.

\section{Notes}

1. For the particular problems which arise when debate participants are not racially homogeneous see Mendelberg and Oleske (2000).

2. McNeil explicated his view in detail in an earlier article (McNeill 1999).

3. Brian Donovan takes a similar position (Donovan 2001).

4. See also Borrows (2001), especially Section II.

5. Some opposing legal perspectives can be found amongst the articles included in Lippert (2000).

6. The writer was quoted making similar points in the Times Colonist, Victoria, 27 December 1997, on p. 1, and wrote an almost identical letter to The Province, Vancouver, 28 December 1997, on p. A50.

7. I am indebted to an anonymous referee for this point.

8. For recent proposals which include discussions of the literature see Leib (2004) and Ackerman and Fishkin (2004).

\section{References}

Ackerman, B. \& Fiskin, J. (2004) Deliberation Day (New Haven, CT: Yale University Press). Benhabib, S. (2002) The Claims of Culture (Princeton, NJ: Princeton University Press).

Bohman, J. (1996) Public Deliberation (Cambridge, MA: MIT Press).

Borrows, J. (2001) Domesticating doctrines: peoples after the Royal Commission. McGill Law Journal, 46, pp. 615-661.

British Columbia (1998/99) Legislative Assembly. Debates $36^{\text {th }}$ Parliament $3^{\text {rd }}$ Session.

Brown, M. (1997) Court ruling will devastate economy, Globe and Mail, 27 December 1997, p. D7.

Cairns, A.C. (2000). Citizens Plus. (Vancouver, BC: UBC Press).

Canada, Attorney General of (1997). Factum. On file with the Supreme Court of Canada.

Canada (1998) Parliament. House of Commons Debates $36^{\text {th }}$ Parliament, $1^{\text {st }}$ Session.

Canada (1999) Parliament. House of Commons Debates $36^{\text {th }}$ Parliament, $2^{\text {nd }}$ Session.

Christie, G. (2000-2001) Delgamuukw and the protection of aboriginal land interests, Ottawa Law Review, 32, pp. 85-115.

Cunningham, D. (1998) I am, therefore I was, New Brunswick Telegraph Journal, 2 February 1998.

Delgamuиkw v. British Columbia (1997) 3 S.C.R. 1010 [cited as Delgamuиkw (S.C.)].

Delgamuukw v. The Queen Reasons For Judgment (1991) No. 0843 Smithers Registry, March 8, 1991 [cited as Delgamuиkw (trial)].

Delgamuиkw v. The Queen (1993) Canadian Native Reporter 5 [cited as Delgamuиkw (appeal)].

Donovan, B. (2001) The evolution and present status of common law aboriginal title in Canada: the law's crooked path and the hollow promise of Delgamuukw, U.B.C. Law Review, 35(1), pp. 41-90.

Dryzek, J.S. (2001) Deliberative Democracy and Beyond (Oxford: Oxford University Press).

Elliott, D.W. (1998) Delgamuukw: back to court, Manitoba Law Journal, 1998, pp. 97-132.

Ely, G. (1992) Nations, publics, and political cultures, in: Calhoun, C. (Ed.), Habermas and the Public Sphere, pp. 289-339 (Cambridge, MA: MIT Press).

Financial Post (1997) Business needs assurance on aboriginal land claims, Financial Post, 16 December 1997, p. 26.

Flanagan, W.F. (1998) Piercing the veil of real property law: Delgamuukw v. British Columbia. Queen's Law Journal, 24, pp. 279-326. 
Fournier, S. (1998) 'We will never surrender land': after the Delgamuukw ruling, leasers vow they'll never give up the aboriginal title they're claiming in much of B.C., The Province, 19 April, p. A44.

Fraser, N. (1992) Rethinking the public sphere, in: Calhoun, C. (Ed.), Habermas and the Public Sphere, pp. 109-142 (Cambridge, MA: MIT Press).

Gibson, G. (1997) The land-claim ruling is a breathtaking mistake, Globe and Mail, 16 December 1997, p. A21.

Gitksan Hereditary Chiefs (1997) Factum. On file with the Supreme Court of Canada.

Gitksan and Wet'suwet'en Hereditary Chiefs (1989) The Spirit of the Lands (Gabriola: Reflections).

Glavin, T. (1998) Relax, the sky is not falling, Globe and Mail, 19 June, p. A19.

Globe and Mail (1997) Canadian law, Indian land, Globe and Mail, 13 December, p. D6.

Gray, J. (1998) Who owns this land?, Globe and Mail, 6 June, pp. A1, A10.

Habermas, J. (1996) Between Facts and Norms (Cambridge: MIT Press).

Hume, S. (1998a) Aboriginal rights foes don’t know history, Vancouver Sun, 24 March, p. G4.

Hume, S. (1998b) Land ruling offers us an opportunity: The Delgamuukw case gives Canada chance to serve as a moral standard for the world, Vancouver Sun, 7 February, p, G5.

James, M.R. (1999) Tribal sovereignty and the intercultural public sphere, Philosophy and Social Criticism, 25(5), pp. 57-86.

James, M.R. (2003) Communicative action, strategic action and inter-group dialogue, European Journal of Political Theory, 2(2), pp. 157-182.

Joffee, P. (2000) Assessing the Delgamuukw principles: national implications and potential effects in Quebec, McGill Law Journal, 45, pp. 155-208.

Joslin, T. (1998) No going back, Globe and Mail, 14 April, p. A18.

Leib, E.J. (2004) Deliberative Democracy in America (University Park, PA: The Pennsylvania State University Press).

Lippert, O. (Ed.) (2000) Beyond the Nass Valley National Implications of the Supreme Court's Delgamuukw Decision (Vancouver, BC: The Fraser Institute).

Macklem, P. (1995) Normative dimensions of an aboriginal right of self-government, Queens Law Journal, 21, pp. 173-219.

Macklem, P. (2001) Indigenous Difference and the Constitution of Canada (Toronto, ON: University of Toronto Press).

Manning, P. (1998) Parliament, not judges must make the laws of the land, Globe and Mail, 16 June, p. A21.

McBride, C. (2003) Consensus, legitimacy, and the exercise of judgment in political deliberation, Critical Review of International Social and Political Philosophy, 6(3), pp. 104-128.

McNeil, K. (1999) The onus of proof of aboriginal title, Osgoode Hall Law Journal, 37, pp. 775-803.

McNeil, K. (2001) Aboriginal rights in transition: reassessing Aboriginal title and governance, The American Review of Canadian Studies, 31, pp. 317-329.

Mendelberg, T. (2002) The deliberative citizen: theory and practice, in: Carpini, M.X.D. (2002) Political Decision Making, Deliberation and Participation, pp. 151-194 (Greenwich, CT: JAI Press).

Mendelberg, T. \& Oleske, J. (2000) Race and deliberation, Political Communication, 17, pp. 169-191.

Nozick, R. (1974) Anarchy State and Utopia (New York: Basic Books).

Ottawa Citizen (1998) Delgamuukw-up, Ottawa Citizen, June 13, p. B5.

Pellizzoni, L. (2001) The myth of the best argument: power, deliberation and reason, British Journal of Sociology, 52(1), pp. 59-86.

Persky, S. (1998) Settlement of B.C. was actually a resettlement, timely book argues, 16 January, p. A19.

Province of British Columbia (1997) Factum. On file with the Supreme Court of Canada.

Robson, J. (1998) Native oral history is not a science, New Brunswick Telegraph Journal, 23 July.

Rawls, J. (1993) Political Liberalism (New York: Columbia University Press).

Rawls, J. (1999) The idea of public reason revisited, in: Freeman, S. (Ed.), John Rawls Collected Papers, pp. 388-414 (Cambridge, MA and London: Harvard University Press). 
Russell, P.H. (1998) High courts and the rights of aboriginal peoples: the limits of judicial independence, Saskatchewan Law Review, 61, pp. 247-276.

Shapiro, I. (1999) Enough of deliberation, politics is about interests and power, in: Macedo, S. (Ed.), Deliberative Politics: Essays on Democracy and Disagreement, pp. 28-38 (Oxford: Oxford University Press).

Simpson, J. (1998) The secession ruling will be less important than B.C.'s Delgamuukw, Globe and Mail, 17 February, p. A18.

Sunstein, C.R.(2002) The law of group polarization, The Journal of Political Philosophy, 10, pp. 175-195.

Tennant, P. (1992) The place of Delgamuukw in British Columbia history and politics - and vice versa, in: Cassidy, F. (Ed.), Aboriginal Title in British Columbia: Delgamuukw v. The Queen, pp. 73-91 (Lantzville \& Montreal: Dolichan Books and The Institute for Research on Public Policy).

Valadez, J.M. (2001) Deliberative Democracy, Political Legitimacy, and Self-Determination in Multicultural Societies (Boulder, CO: Westview Press).

Wet'suwet'en Hereditary Chiefs (1997) Factum. On file with the Supreme Court of Canada.

Wilkins, K. (2000) Take your time and do it right: Delgamuukw, self-government rights and the pragmatics of advocacy, Manitoba Law Journal, 27(2), pp. 241-272.

Young, I.M. (2000) Inclusion and Democracy (Oxford: Oxford University Press). 